\title{
Purification, Some Properties and Possible Physiological Role of an Extracellular Cobalamin Binding Protein from Euglena gracilis
}

\author{
By FUMIO WATANABE, YOSHIHISA NAKANO, ${ }^{*}$ HIROTOMO OCHI AND \\ SHOZABURO KITAOKA \\ Department of Agricultural Chemistry, University of Osaka Prefecture, Sakai, Osaka 591, Japan
}

(Received 7 July 1987; revised 3 November 1987)

\begin{abstract}
The extracellular cobalamin (Cbl) binding protein from Euglena gracilis was purified and some properties of the protein were studied for the elucidation of its physiological role. The protein was purified about 20 -fold with a yield of $15 \%$ and was homogeneous on PAGE. SDS-PAGE indicated that the protein had a single type of polypeptide of $M_{\mathrm{r}} 56000$. The protein could bind some $\mathrm{Cbl}$ analogues with different $\beta$-coordination moieties, over a wide range of $\mathrm{pH}$ values from 4.0 to 9.0 , and the $K_{\mathrm{s}}$ value for cyanocobalamin was $1.1 \mathrm{nM}$. The extracellular $\mathrm{Cbl}$ binding protein was located on the cell surface of $E$. gracilis, probably bound in the muciferous layer.
\end{abstract}

\section{INTRODUCTION}

In higher animals, intestinal absorption and subsequent plasma transport of cobalamin ( $\mathrm{Cbl})$ is mediated by specific binding proteins, e.g. intrinsic factor (Allen \& Mehlman, 1973) and transcobalamin II (Allen \& Majerus, 1972). These binding proteins have been purified and characterized, and their physiological roles have been explained (Herbert, 1959; Rappazzo \& Hall, 1972). Heat labile $\mathrm{Cbl}$ binding macromolecules have been reported to be formed in the culture broth of some micro-organisms (Ford, 1958), but lack of detailed study on these proteins has limited our understanding of their physiological functions.

An extracellular Cbl binding protein has been reported for Euglena gracilis (Kristensen, 1956) and was purified several-fold from the culture broth (Daisley, 1970). Our previous study (Watanabe et al., 1987) has shown that E. gracilis $\mathrm{Cbl}$ binding proteins are distributed in the cytosol, mitochondria and microsomes, and that the extracellular $\mathrm{Cbl}$ binding protein is immunologically identical to the cytosolic one. In the present work we describe the extensive purification of the extracellular $\mathrm{Cbl}$ binding protein and discuss the possible physiological role of this protein.

\section{METHODS}

Organism and culture. E. gracilis SM-ZK, a streptomycin-bleached mutant of $E$. gracilis Z, was cultured for $5 \mathrm{~d}$ at $27^{\circ} \mathrm{C}$ and $2000 \mathrm{~lx}$ in a Cbl-limited $\left(0.05 \mu \mathrm{g}^{-1}\right)$ Koren-Hutner medium (Koren \& Hutner, 1967).

$\mathrm{Cbl}$ binding assay. This was done as described previously (Watanabe et al., 1988).

Purification of extracellular Cbl binding protein. All purification procedures were done at $0-4{ }^{\circ} \mathrm{C}$. A $5 \mathrm{~d} E$. gracilis culture (15l) was centrifuged at $2000 \mathrm{~g}$ for $5 \mathrm{~min}$ to remove the cells. o-Phenanthroline ( $5 \mathrm{mM}$ ) an E. gracilis extracellular proteinase inhibitor, and Hyflo super-cel $(200 \mathrm{~g})$ were added to the supernatant. The suspension was filtered to completely remove $E$. gracilis cells and the filtrate was used as a crude preparation of extracellular $\mathrm{Cbl}$ binding protein. The filtrate (14.7 l) was concentrated to a final volume of 1.751 using polyethylene glycol (PEG) 20000 , and dialysed overnight against 16 litres $10 \mathrm{mM}$-potassium phosphate buffer, $\mathrm{pH} 7 \cdot 2$. The dialysed solution was applied to a column $(2 \times 10 \mathrm{~cm})$ of DEAE-cellulose equilibrated with $10 \mathrm{~mm}$-potassium phosphate buffer,

Abbreviations: $\mathrm{Cbl}$, cobalamin; $\mathrm{CN}-\mathrm{Cbl}$, cyanocobalamin; OH-Cbl, hydroxocobalamin; $\mathrm{Me}-\mathrm{Cbl}$, methylcobalamin; Ado-Cbl, 5'-deoxyadenosylcobalamin; 2-AMP-Cbl, 2-amino-2-methylpropanolylcobalamin. 
pH 7.2. The column was washed with $100 \mathrm{ml}$ of the same buffer and eluted with $400 \mathrm{ml}$ of a linear $(0-0.5 \mathrm{M}) \mathrm{KCl}$ gradient in the same buffer. The active fractions $(178 \mathrm{ml})$ were combined and dialysed overnight against 31 of the same buffer. The dialysed solution was applied to a column $(1 \times 5 \mathrm{~cm})$ of DEAE-cellulose equilibrated with $10 \mathrm{~mm}$-potassium phosphate buffer, $\mathrm{pH} 7 \cdot 2$, and eluted with $200 \mathrm{ml}$ of a linear $(0-0.4 \mathrm{M}) \mathrm{KCl}$ gradient in this buffer. The active fractions were combined and concentrated to a final volume of $2 \mathrm{ml}$ by use of PEG 20000 . The concentrated solution was applied to a column $(1.5 \times 90 \mathrm{~cm})$ of Sephacryl S-300 equilibrated with $100 \mathrm{mM}-$

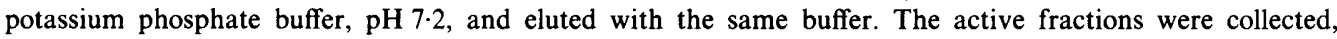
concentrated to a final volume of $1 \mathrm{ml}$ by use of PEG 20000 and stored at $-20^{\circ} \mathrm{C}$ until use.

$P A G E$. SDS-PAGE was done under the same conditions and using the same standards as described in Watanabe et al. (1988).

Western blotting. Electrophoretic transfer to a nitrocellulose sheet (TM-2, $0.45 \mu \mathrm{m}$ ) was done at $50 \mathrm{~V}$ for $90 \mathrm{~min}$ at $0{ }^{\circ} \mathrm{C}$ as described by Burnette (1981). E. gracilis extracellular $\mathrm{Cbl}$ binding protein on the nitrocellulose sheet was detected immunologically with antibody against an $E$. gracilis cytosolic $\mathrm{Cbl}$ binding protein (Watanabe et al., 1987) and horseradish-peroxidase-anti-rabbit IgG goat serum conjugate as described by Towbin et al. (1979).

Properties of the protein. The $\mathrm{pH}$ dependency was determined by using citrate buffer for $\mathrm{pH} 2 \cdot 0-5 \cdot 0$, Tris/acetate buffer for $\mathrm{pH} 5 \cdot 0-9 \cdot 0$, and glycine/ $\mathrm{NaOH}$ buffer for $\mathrm{pH} 9 \cdot 0-11 \cdot 0$, all at $100 \mathrm{~mm}$, as the dialysis buffers. The $\mathrm{pH}$ stability was determined by using the protein pre-treated at various $\mathrm{pH}$ values for $10 \mathrm{~min}$ at $45^{\circ} \mathrm{C}$. The thermal stability was determined by using the protein pre-incubated at various temperatures between 0 and $70^{\circ} \mathrm{C}$ for $10 \mathrm{~min}$ at $\mathrm{pH} 7 \cdot 2$. The $K_{\mathrm{s}}$ value for cyanocobalamin $(\mathrm{CN}-\mathrm{Cbl})$ was calculated from double reciprocal plots of the amount of $\mathrm{Cbl}$ bound to the protein versus the ligand concentration $(0 \cdot 2-20 \mathrm{nM})$. For determination of inhibition of $\mathrm{CN}-\mathrm{Cbl}$ binding activity by some $\mathrm{Cbl}$ analogues, hydroxocobalamin $(\mathrm{OH}-\mathrm{Cbl})$, methylcobalamin $(\mathrm{Me}-\mathrm{Cbl}), 5^{\prime}-$ deoxyadenosylcobalamin (Ado-Cbl) (all at $10 \mathrm{nM}$ ) and $60 \mathrm{nM}$-2-amino-2-methylpropanolylcobalamin (2-AMP$\mathrm{Cbl}$ ) were added into the dialysis buffer containing $10 \mathrm{nM}-\left[{ }^{3} \mathrm{H}\right] \mathrm{CN}-\mathrm{Cbl}$. For experiments on effects of thiolreagents [mersalyl acid, 5,5'-dithio-bis(2-nitrobenzoic acid), $N$-ethylmaleimide, iodoacetamide, dithiothreitol, 2mercaptoethanol and reduced glutathione] and the chelater EDTA, each reagent, at $1 \mathrm{~mm}$, was added to the dialysis bag and buffer at $1 \mathrm{mM}$. All experiments were done with the purified Cbl binding protein ( $2-4 \mu \mathrm{g}$ protein). All results presented are mean values of three experiments.

Inhibition of Cbl uptake by the antibody against E. gracilis cytosolic Cbl binding protein. E. gracilis grown for $5 \mathrm{~d}$ in Cbl-limited medium was centrifuged at $2000 \mathrm{~g}$ for $5 \mathrm{~min}$ to collect cells, which were washed twice with $10 \mathrm{mM}$ sodium phosphate buffer, pH 7.2, containing $0.9 \%(\mathrm{w} / \mathrm{v}) \mathrm{NaCl}$, suspended in the same buffer containing glutamate and glucose (both $10 \mathrm{~mm}$ ) and incubated with shaking at $27^{\circ} \mathrm{C}$ for $3 \mathrm{~h}$. The E. gracilis cells $\left(10^{6}\right.$ cells) were pre-treated with the antibody against E. gracilis cytosolic binding protein at $27^{\circ} \mathrm{C}$ for $2 \mathrm{~h}$. The Cbl uptake was started by adding $\left[{ }^{3} \mathrm{H}\right] \mathrm{CN}-\mathrm{Cbl}\left(9 \cdot 2 \mathrm{Ci} \mathrm{mmol}^{-1}, 340 \mathrm{GBq} \mathrm{mmol}{ }^{-1}\right)$ at $10 \mathrm{nM}$ to the pre-treated E. gracilis cell suspension, allowed to proceed for $15 \mathrm{~s}$ or for $2 \mathrm{~min}$ at $27^{\circ} \mathrm{C}$ and stopped by filtering through a membrane filter (TM-2P). The membrane was washed twice with $10 \mathrm{mM}$-sodium phosphate buffer, pH $7 \cdot 2$, containing $0 \cdot 9 \% \mathrm{NaCl}$ at $27^{\circ} \mathrm{C}$. The membrane filters were dried and counted with a liquid scintillation counter (Aloka, LSC 903).

Protein determination. Protein was determined according to Bradford (1976) using BSA as a standard.

Chemicals. $\left[{ }^{3} \mathrm{H}\right] \mathrm{CN}-\mathrm{Cbl}\left(9 \cdot 2 \mathrm{Ci} \mathrm{mmol}^{-1}, 340 \mathrm{GBq} \mathrm{mmol}^{-1}\right)$ was obtained from New England Nuclear. CN-Cbl, $\mathrm{OH}-\mathrm{Cbl}$, Ado-Cbl, Me-Cbl and horseradish peroxidase-anti-rabbit IgG goat serum conjugate were obtained from Sigma. Sephacryl S-300 and the electrophoresis calibration kit were obtained from Pharmacia. Membrane filters (TM-2 and TM-2P) were purchased from Toyo Roshi.

\section{RESULTS AND DISCUSSION}

\section{Extracellular Cbl binding activity during growth}

The $\mathrm{Cbl}$ binding activity reached a maximum $\left[0.18 \mathrm{pmol}(\mathrm{ml} \mathrm{medium})^{-1}\right]$ in the early stationary phase and remained constant thereafter up to $9 \mathrm{~d}$ (Fig. 1). The results indicate that the extracellular $\mathrm{Cbl}$ binding protein is not secreted into the culture medium until E. gracilis cells reach the stationary phase.

\section{Purification of the extracellular $\mathrm{Cbl}$ binding protein}

This was done as described in Methods; the results are summarized in Table 1. The Cbl binding protein was purified about 20 -fold with a yield of $15 \%$ from the culture medium of $E$. gracilis grown for $5 \mathrm{~d}$. The purified $\mathrm{Cbl}$ binding protein showed a specific activity of $936.6 \mathrm{pmol}$ (mg protein $)^{-1}$, which was more than 20 times as pure as the preparation reported by Daisley (1970). Disc PAGE in $7.5 \%(\mathrm{w} / \mathrm{v})$ acrylamide at $\mathrm{pH} 9.4$ of the purified protein revealed a single band. 


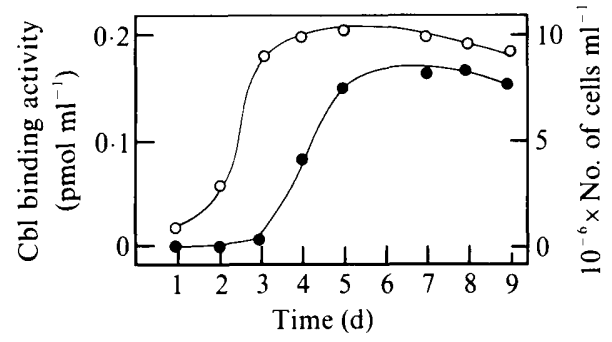

Fig. 1. Extracellular $\mathrm{Cbl}$ binding activity during E. gracilis growth. E. gracilis cells $\left(23.5 \times 10^{6}\right.$ cells), which were pre-cultured for $5 \mathrm{~d}$ in Koren-Hutner medium, were transferred to Cbl-limited medium $(150 \mathrm{ml})$. Samples $(1 \mathrm{ml})$ were centrifuged $(6000 \mathrm{~g}, 5 \mathrm{~min})$ and the supernatant was used as a crude extracellular $\mathrm{Cbl}$ binding protein preparation. The data represent the mean of values from four experiments. $\mathrm{Cbl}$ binding activity; $\mathrm{O}$, cell number.

Table 1. Purification of the extracellular Cbl binding protein from an E. gracilis culture

The data are typical of purification data from five experiments.

\begin{tabular}{lccccc}
\multicolumn{1}{c}{ Step } & $\begin{array}{c}\text { Volume } \\
(\mathrm{ml})\end{array}$ & $\begin{array}{c}\text { Protein } \\
(\mathrm{mg})\end{array}$ & $\begin{array}{c}\text { Total activity } \\
(\text { pmol Cbl bound) }\end{array}$ & $\begin{array}{c}\text { Specific activity } \\
\text { [pmol Cbl bound } \\
(\mathrm{mg} \text { protein) }\end{array}$ & $\begin{array}{c}\text { Recovery } \\
(\%)\end{array}$ \\
Culture medium & 14700 & $104 \cdot 7$ & 4789.9 & $45 \cdot 7$ & 100 \\
PEG 20000 & 1750 & $70 \cdot 0$ & $4585 \cdot 1$ & $65 \cdot 5$ & $95 \cdot 8$ \\
First DEAE-cellulose & 178 & $10 \cdot 7$ & $2561 \cdot 3$ & $239 \cdot 8$ & $53 \cdot 5$ \\
Second DEAE-cellulose & 2 & $2 \cdot 5$ & $1354 \cdot 5$ & $541 \cdot 8$ & $28 \cdot 3$ \\
Sephacryl S-300 & 1 & $0 \cdot 8$ & $749 \cdot 3$ & $936 \cdot 6$ & $15 \cdot 6$
\end{tabular}

Some properties of the purified extracellular $\mathrm{Cbl}$ binding protein

The $\mathrm{pH}$ dependency for the binding of $\mathrm{Cbl}$ to the protein, and the $\mathrm{pH}$ stability, were very

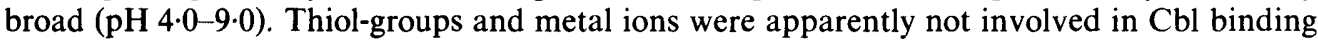
since it was not affected by thiol inhibitors or EDTA. The inhibition of $\mathrm{CN}-\mathrm{Cbl}$ binding activity by the $\mathrm{Cbl}$ analogues $\mathrm{OH}-\mathrm{Cbl}, \mathrm{Me}-\mathrm{Cbl}$ and $\mathrm{Ado}-\mathrm{Cbl}(45 \%, 35 \%$ and $46 \%$ inhibition, respectively) but not by 2 -AMP-Cbl, suggests that the $\alpha$-coordination moiety of the $\mathrm{Cbl}$ molecule is more important for formation of the protein- $\mathrm{Cbl}$ complex than the $\beta$-coordination moiety. These properties were similar to those of the cytosolic and pellicular $\mathrm{Cbl}$ binding proteins, but the extracellular $\mathrm{Cbl}$ binding protein was stable up to $30^{\circ} \mathrm{C}$ and therefore showed a lower thermal stability than these $\mathrm{Cbl}$ binding proteins (Watanabe et al., 1987, 1988). The extracellular $\mathrm{Cbl}$ binding protein showed a lower affinity for $\mathrm{CN}-\mathrm{Cbl}\left(K_{\mathrm{s}}=1 \cdot 1 \mathrm{nM}\right)$ than did the pellicular binding proteins (Watanabe et al., 1988), but had a similar affinity to the cytosolic binding proteins $\left(K_{\mathrm{s}}=1-2 \mathrm{nM}\right)$ (Watanabe et al., 1987). The $M_{\mathrm{r}}$ of the polypeptide of the extracellular $\mathrm{Cbl}$ binding protein was estimated to be 56000 by SDS-PAGE, while those of the cytosolic and pellicular proteins were 66000 and 38000, respectively (Watanabe et al., 1987, 1988). The native extracellular $\mathrm{Cbl}$ binding protein was eluted in the void fraction on Sephacryl S-300 gel filtration, indicating that the protein has an $M_{\mathrm{r}}$ of more than 1500000 , unless nonspecific aggregation occurs. The $M_{\mathrm{r}}$ of the native protein could not be determined accurately since there is no information available on aggregation. The cytosolic and pellicular $\mathrm{Cbl}$ binding proteins showed identical behaviour on gel filtration (Watanabe et al., 1987, 1988).

\section{Possible location of the extracellular Cbl binding protein}

The extracellular $\mathrm{Cbl}$ binding protein is immunologically identical to the cytosolic binding proteins (Watanabe et al., 1987). In Western blotting, after SDS-PAGE of the crude extracellular $\mathrm{Cbl}$ binding protein, no proteins other than that with an $M_{\mathrm{r}}$ of 56000 were detected when immunoreacted with the antibody against the cytosolic $\mathrm{Cbl}$ binding protein. Moreover, $E$. 

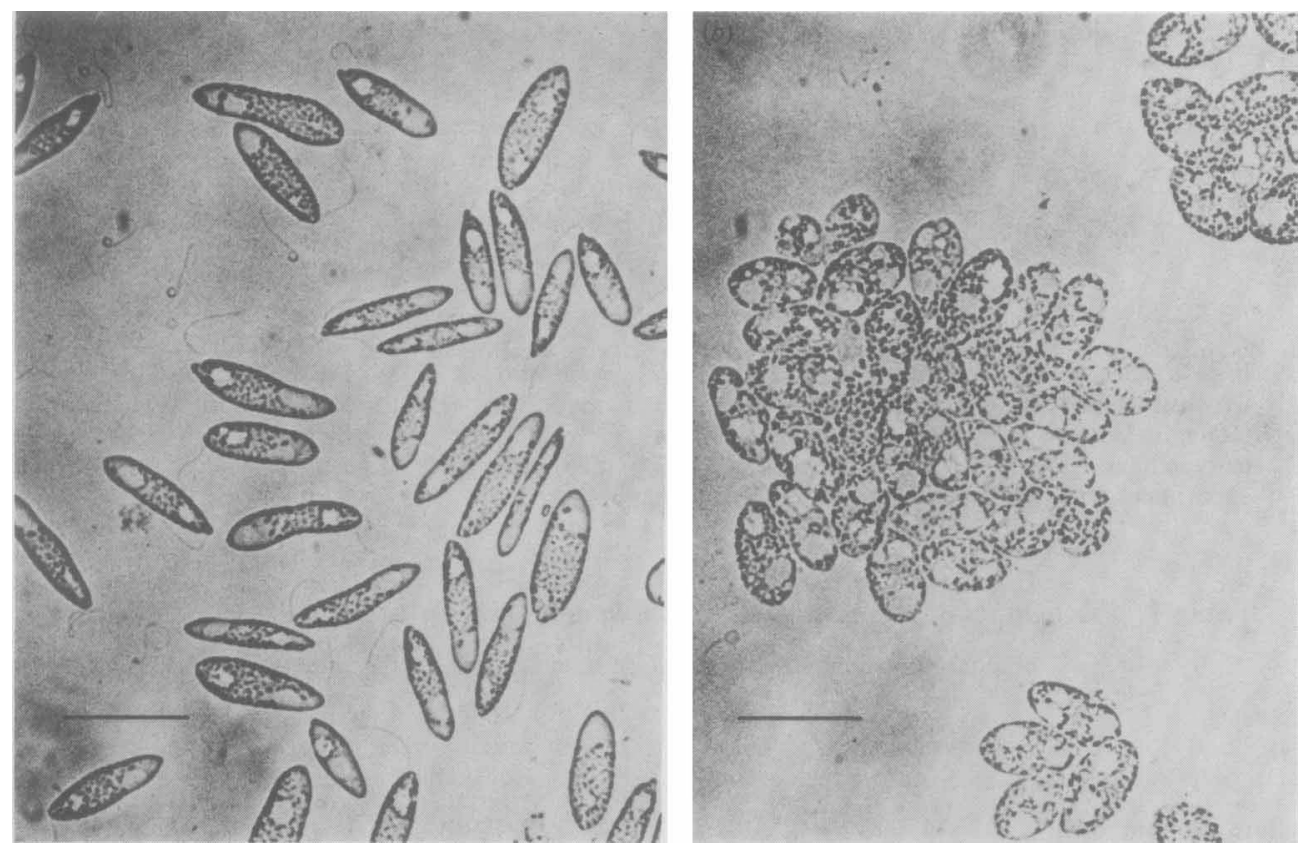

Fig. 2. Aggregation of $E$. gracilis cells by antibody against the cytosolic $\mathrm{Cbl}$ binding protein. E. gracilis cells were pre-treated with either unimmunized-rabbit serum $(a)$ or antibody against the cytosolic $\mathrm{Cbl}$ binding protein $(b)$. Bars, $100 \mu \mathrm{m}$.

gracilis cells, when treated with the antibody, aggregated (Fig. 2). The ability of the antibody to agglutinate the cells provides evidence that the extracellular $\mathrm{Cbl}$ binding protein occurs as a surface component, probably embedded in the muciferous layer which surrounds the E. gracilis cell. These results suggest that the extracellular $\mathrm{Cbl}$ binding protein is not due to the leakage of intracellular $\mathrm{Cbl}$ binding proteins as a result of cell destruction but that the cytosolic $\mathrm{Cbl}$ binding protein, after some processing, is secreted and linked to the muciferous layer. The destruction of the muciferous layer by collision among E. gracilis cells in the stationary phase may cause the leakage of the extracellular $\mathrm{Cbl}$ binding protein into the culture medium.

\section{Physiological role of the extracellular Cbl binding protein}

The kinetics of $\mathrm{Cbl}$ uptake by $E$. gracilis have been reported to be biphasic (Sarhan et al., 1980), and we have shown that $E$. gracilis pellicular $C b l$ binding proteins take part in the biphasic uptake system (Watanabe et al., 1988). The extracellular Cbl binding protein, which is probably located on the cell surface, is not considered to be involved in this biphasic process since neither the $\mathrm{Cbl}$ uptake in the initial rapid phase nor that in the slower secondary phase were inhibited by treating the cells with the antibody against the cytosolic $\mathrm{Cbl}$ binding protein. The results indicate that the extracellular $\mathrm{Cbl}$ binding protein functions as an accumulator of $\mathrm{Cbl}$ in the cell surface region. The evidence presented suggests that $E$. gracilis firstly binds the trace amount of $\mathrm{Cbl}$ in the environment using the extracellular $\mathrm{Cbl}$ binding protein; the subsequent uptake of the accumulated $\mathrm{Cbl}$ in the cell surface region would also involve the pellicular $\mathrm{Cbl}$ binding proteins which act as the $\mathrm{Cbl}$ carrier proteins in the E. gracilis cell membrane.

\section{REFERENCES}

Allen, R. H. \& Majerus, P. W. (1972). Isolation of vitamin $\mathbf{B}_{12}$-binding proteins using affinity chromatography. III. Purification and properties of human plasma transcobalamin II. Journal of Biological Chemistry 247, 7709-7717
Allen, R. H. \& Mehlman, C. S. (1973). Isolation of gastric vitamin $B_{12}$-binding proteins using affinity chromatography. I. Purification and properties of human intrinsic factor. Journal of Biological Chemistry 248, 3660-3669. 
BRADFORD, M. M. (1976). A rapid and sensitive method for the quantitation of microgram quantities of protein utilizing the principle of protein-dye binding. Analytical Biochemistry 72, 248-254.

BURNETTE, W. N. (1981). 'Western blotting': electrophoretic transfer of proteins from sodium dodecyl sulfate-polyacrylamide gels to unmodified nitrocellulose and radiographic detection with antibody and radio-iodinated protein A. Analytical Biochemistry 112, 195-203.

DAISLEY, K. W. (1970). The occurrence and nature of Euglena gracilis proteins that bind vitamin $\mathrm{B}_{12}$. International Journal of Biochemistry 1, 561-574.

FORD, J. E. (1958). $B_{12}$-vitamins and growth of the flagellate Ochromonas malhamensis. Journal of General Microbiology 19, 161-172.

HERBERT, V. (1959). Mechanism of intrinsic factor action in everted sacs of rat small intestine. Journal of Clinical Investigation 38, 102-109.

KOREN, L. E. \& HuTner, S. H. (1967). High-yield media for photosynthesizing Euglena gracilis. Journal of Protozoology 14 (Supplement), 17.

KRISTENSEN, H. P. O. (1956). Vitamin $\mathbf{B}_{12}$-binding factor formed in cultures of Euglena gracilis. Acta physiologica scandinavica 37, 8-13.
Rappazzo, M. E. \& Hall, C. A. (1972). Transport function of transcobalamin II. Journal of Clinical Investigation 51, 1915-1918.

Sarhan, F., Houde, M. \& Cheneval, J. P. (1980). The role of vitamin $B_{12}$ binding in the uptake of the vitamin by Euglena gracilis. Journal of Protozoology 27, 235-238.

Towbin, H., Staehelin, T. \& GoRdon, J. (1979) Electrophoretic transfer of proteins from polyacrylamide gels to nitrocellulose sheets: procedure and some applications. Proceedings of the National Academy of Sciences of the United States of America 76, 4350-4354.

Watanabe, F., Nakano, Y. \& Kitaoka, S. (1987). Purification and some properties of cytosolic cobalamin binding protein in Euglena gracilis. Biochemical Journal 247, 679-685.

Watanabe, F., Ito, T., Tabuchi, T., Nakano, Y. \& KITAOKA, S. (1988). Isolation of pellicular cobalamin-binding proteins of the cobalamin uptake system of Euglena gracilis. Journal of General Microbiology 134, 67-74. 